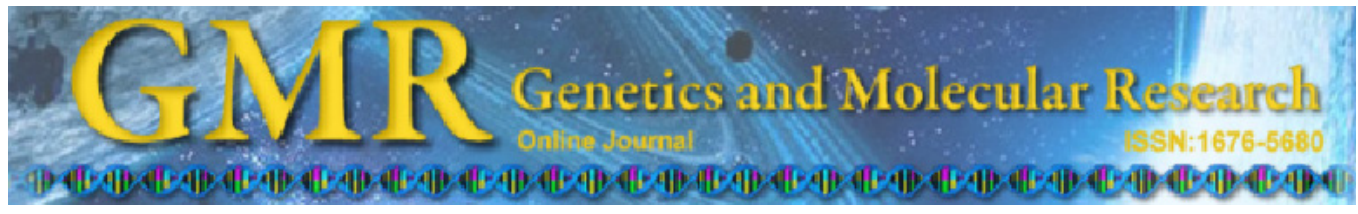

\title{
Detection of bacterial blight resistance genes in basmati rice landraces
}

I. Ullah ${ }^{1}$, S. Jamil ${ }^{1}$, M.Z. Iqbal ${ }^{1}$, H.L. Shaheen ${ }^{1}$, S.M. Hasni ${ }^{1}$, S. Jabeen ${ }^{1}$, A. Mehmood ${ }^{1}$ and M. Akhter ${ }^{2}$

${ }^{1}$ Agricultural Biotechnology Research Institute, Faisalabad, Pakistan

${ }^{2}$ Rice Research Institute, Kala Shah Kaku, Pakistan

Corresponding author: I. Ullah

E-mail: ihsan.ullah_tlw@yahoo.com

Genet. Mol. Res. 11 (3): 1960-1966 (2012)

Received November 3, 2011

Accepted June 25, 2012

Published July 20, 2012

DOI http://dx.doi.org/10.4238/2012.July.20.1

ABSTRACT. Aromatic basmati rice is vulnerable to bacterial
blight disease. Genes conferring resistance to bacterial blight
have been identified in coarse rice; however, their incorporation
into basmati varieties compromises the prized basmati aroma. We
identified bacterial blight resistance genes Xa4, xa5, Xa7, and
xa13 in 52 basmati landraces and five basmati cultivars using
PCR markers. The Xa7 gene was found to be the most prevalent
among the cultivars and landraces. The cultivars Basmati-385 and
Basmati-2000 also contained the Xa4 gene; however, xa5 and xal3
were confined to landraces only. Ten landraces were found to have
multiple resistance genes. Landraces Basmati-106, Basmati-189
and Basmati-208 contained Xa4 and Xa7 genes. Whereas, landraces
Basmati-122, Basmati- 427 , Basmati- 433 were observed to have $x a 5$
and Xa7 genes. Landraces Basmati- 48 , Basmati-51A, Basmati-334,
and Basmati-370A possessed Xa7 and xa13 genes. The use of
landraces containing recessive genes $x a 5$ and $x a 13$ as donor parents
in hybridization with cultivars Basmati-385 and Basmati-2000,
which contain the genes Xa4 and Xa7, will expedite efforts to
develop bacterial blight-resistant basmati rice cultivars through 
marker assisted selection, based on a pyramiding approach, without compromising aroma and grain quality.

Key words: Basmati rice; Landraces; Bacterial blight resistance; PCR markers

\section{INTRODUCTION}

Rice (Oryza sativa L.) is one of the oldest domesticated crops, which provides food for more than half of the world's population and constitutes a major source of calories for urban and rural inhabitants (Khush, 2005). Basmati is one of the premium rice groups, cultivated in the Himalayan foothill regions of Pakistan and India. The demand for basmati rice is markedly increasing worldwide on account of its exotic aroma, sweet taste, and superfine long grains. The productivity and quality of rice is under threat from a number of biotic and abiotic stresses, one of which is bacterial blight (BB). This blight is caused by the Gramnegative proteobacterium Xanthomonas oryzae and is one of the most devastating diseases affecting entire basmati rice acreages and causes severe yield losses of up to $80 \%$ (Srinivasan and Gnanamanickam, 2005), depending on the stage of the crop, cultivar susceptibility and the environmental conditions.

Exploitation of host plant resistance is considered the most effective, economical and environmentally safe measure for controlling BB in combination with management practices. To tackle the BB problem, several attempts have been made to identify and characterize BB-resistance genes. To date, approximately 34 genes ( 23 dominant and 11 recessive) conferring resistance against various strains of $X$. oryzae have been identified (Chen et al., 2011), largely in non-basmati rice. Major resistance genes, including Xa4, xa5, Xa7, $x a 13$, and $X a 21$, have been incorporated into rice cultivars, in order to develop new resistant varieties (Perumalsamy et al., 2010). However, the cultivars containing a single major resistance gene proved susceptible due to pathogen mutation. Recently, pyramiding of more than one major resistance gene has been proven to deliver durable resistance against BB (Rajpurohit et al., 2010).

Conventional breeding tools are inefficient for gene pyramiding, particularly in the case of recessively inherited resistance genes, such as $x a 5$ and $x a 13$. These limitations can be addressed by marker-assisted selection (MAS), which enables the evaluation of the expression status of resistance gene(s) and allows for pyramiding of multiple resistance genes in a desirable genetic background. Polymerase chain reaction (PCR)-based DNA markers for some of these genes have been identified: MP1 and MP2 for Xa4 (Ma et al., 1999), RM122 for $x a 5$ (Chen et al., 1997), M5 for Xa7 (Porter et al., 2003), and RG136 for xal3 (Zhang et al., 1996). These markers have been employed to identify germplasm containing these genes (Blair and McCouch, 1997) and develop rice cultivars with single and multiple resistance genes (Perumalsamy et al., 2010; Rajpurohit et al., 2010). However, these studies have utilized non-aromatic sources as a donor parent in back-cross breeding approaches, which makes it extremely difficult to recover the prized basmati aroma and grain quality.

In this study, we screened basmati landraces for the status of the BB-resistance genes $\mathrm{Xa} 4, \mathrm{Xa} 5, \mathrm{Xa}$, and $\mathrm{xa} 13$; we believe that our findings may accelerate the breed- 
ing efforts for the development of BB-resistant basmati cultivars through pyramiding approaches using MAS.

\section{MATERIAL AND METHODS}

\section{Plant materials}

Fifty-two basmati landraces, 5 basmati cultivars, the susceptible line IR24, and its 4 near-isogenic gene differential lines were evaluated in this study. Leaf samples for all the accessions were collected from the Rice Research Institute, Kala Shah Kaku, Pakistan.

\section{DNA isolation}

Total genomic DNA was isolated from the sampled leaves of each genotype by the cetyltrimethylammonium bromide (CTAB method) with minor modifications. The isolated DNA was quantified using a spectrophotometer (NanoDrop-2000 Thermo Scientific, USA).

\section{DNA markers and PCR amplification}

Previously reported markers were used to analyze the status of the BB-resistance genes $X a 4, x a 5, X a 7$, and $x a 13$ (Table 1). For PCR, a reaction volume of $20 \mu \mathrm{L}$ was set up, containing $2.0 \mu \mathrm{L}$ 10X PCR buffer (50 mM Tris, $\mathrm{pH} 8.3,500 \mathrm{mM} \mathrm{KCl}), 1.5 \mathrm{mM} \mathrm{MgCl}_{2} ; 0.2$ $\mathrm{mM}$ of each dATP, dCTP, dGTP, and dTTP (Fermentas, USA); $0.6 \mu \mathrm{M}$ of each reverse and forward primers (GeneLink); 1 U Taq DNA polymerase (Fermentas), and 50 ng genomic DNA as a template. Amplification was performed in a Mastercycler Gradient (Eppendorf, Germany) with the following temperature cycles: first denaturation step of $94^{\circ} \mathrm{C}$ for $5 \mathrm{~min}$, followed by 35 cycles of $94^{\circ} \mathrm{C}$ for $1 \mathrm{~min}, 55^{\circ} \mathrm{C}$ (variable according to the annealing temperature) for $1 \mathrm{~min}$, and $72^{\circ} \mathrm{C}$ for $1 \mathrm{~min}$ followed by a final extension at $72^{\circ} \mathrm{C}$ for $7 \mathrm{~min}$.

\begin{tabular}{|c|c|c|c|c|c|}
\hline Gene & Located on chromosome & Marker & Type of marker & Primer sequence $\left(5^{\prime}-3^{\prime}\right)$ & Reference \\
\hline Xa4 & 4 & $\begin{array}{l}\text { MP1 } \\
\text { MP2 }\end{array}$ & STS & $\begin{array}{l}\text { ATCGATCGATCTTCACGAGG } \\
\text { TCGTATAAAAGGCATTCGGG }\end{array}$ & Ma et al., 1999 \\
\hline$x a 5$ & 5 & $\begin{array}{l}\text { RM122 F } \\
\text { RM122 R }\end{array}$ & SSR & $\begin{array}{l}\text { GAGTCGATGTAATGTCATCAGTGC } \\
\text { GAAGGAGGTATCGCTTTGTTGGAC }\end{array}$ & Chen et al., 1997 \\
\hline$X a 7$ & 6 & $\begin{array}{l}\text { M5 F } \\
\text { M5 R }\end{array}$ & STS & $\begin{array}{l}\text { CGATCTTACTGGCTCTGCAACTCTGT } \\
\text { GCATGTCTGTGTCGATTCGTCCGTACGA }\end{array}$ & Porter et al., 2003 \\
\hline xal3 & 8 & $\begin{array}{l}\text { RGI36 F } \\
\text { RG136 R }\end{array}$ & STS/HinfI & $\begin{array}{l}\text { TCCCAGAAAGCTACTACAGC } \\
\text { GCAGACTCCAGTTTGACTTC }\end{array}$ & Zhang et al., 1996 \\
\hline
\end{tabular}

\section{PCR analysis}

The amplified products of Xa4 and $x a 5$ were resolved on $6 \%$ polyacrylamide (19:1, acryl:bis) gel, on the OmniPAGE Maxi vertical electrophoresis system (BiocomDirect, UK) and visualised by silver staining. The products of $X a 7$ and $x a 13$ were run on $1.5 \%$ agarose gel, stained 
with ethidium bromide, and documented by the NYXTECHNIK gel documentation system.

The products amplified with the STS marker RG136 for $x a 13$ were digested with restriction enzyme HinfI. The total volume of the restriction was $20 \mu \mathrm{L}(2 \mu \mathrm{L} 10 \mathrm{X}$ buffer tango, $1 \mu \mathrm{L} 10 \mathrm{U} / \mu \mathrm{L}$ restriction enzyme, $7 \mu \mathrm{Ld}_{3} \mathrm{H}_{2} \mathrm{O}$, and $10 \mu \mathrm{L}$ amplified products). The reactions were incubated at $37^{\circ} \mathrm{C}$ for $3 \mathrm{~h}$. The restricted fragments were separated on $1.5 \%$ agarose gel. The amplified fragments of all the landraces and basmati cultivars were scored according to their respective resistance (IRBB near-isogenic lines) and susceptible (IR24) lines.

\section{RESULTS}

Fifty-two basmati landraces and 5 basmati cultivars, namely, Super Basmati, Basmati-370, Basmati-2000, Basmati-Pak, and Basmati-385, were evaluated to determine the resistance and susceptibility status for 4 BB-resistance genes, namely, Xa4, $x a 5, X a 7$, and $x a 13$, by using PCR-based markers. The susceptible line IR24 and its 4 near-isogenic lines, IRBB4 (Xa4), IRBB5 ( $x a 5$ ), IRBB7 (Xa7), and IRBB13 ( $x a 13$ ), were included as gene differential lines.

Amplification of the sequence-tagged site (STS) marker MP1-2, which is linked to $X a 4$, revealed the presence of a 150-bp fragment specific for Xa4-mediated BB resistance in the differential line IRBB4, and a 120-bp fragment corresponding to the susceptible line IR24 (Figure 1A). Three landraces, Basmati-106, Basmati-189 and Basmati-208, harbored the resistance allele, whereas the landrace Basmati-122 exhibited the heterozygous pattern. Among the 5 tested cultivars, Basmati-2000 and Basmati-385 showed homozygous resistance status for the $\mathrm{Xa} 4$ gene.

Screening for the recessive $x a 5$ resistance gene by the amplification of the microsatellite marker RM122, which was employed to track the resistant and susceptible amplicons of 241 and $231 \mathrm{bp}$, respectively, revealed that landraces Basmati-122, Basmati-427 and Basmati-433 had a homozygous status for the resistance allele, whereas landrace Basmati-208 showed both resistance and susceptible alleles. However, none of the 5 tested commercial basmati cultivars exhibited the presence of resistance allele (Figure 1B).

Application of the STS marker M5 on the susceptible line IR24 and Xa7 differential line IRBB7 produced fragments of 1170 and $294 \mathrm{bp}$, respectively, which corresponded to the reported sizes for resistance and susceptible alleles (Figure 1C). The $\mathrm{Xa} 7$ gene was found to be most prevalent in the material studied. The entire set of 52 landraces and 5 commercial cultivars amplified an amplicon of a 294-bp fragment specific for Xa7, except Basmati-114, which yielded a susceptible allele.

CAPS marker RG136 linked to the recessive resistant BB gene xal3 amplified a monomorphic product of $1100 \mathrm{bp}$ in all the genotypes studied. Digestion of the PCR product with the restriction enzyme HinfI generated 3 fragments of approximately 520, 450, and 130 $\mathrm{bp}$ in the differential line IRBB13 and landraces Basmati-48, Basmati-51A, Basmati-334, and Basmati-370A, while the susceptible line IR24, 5 basmati cultivars, and 48 landraces produced only 2 fragments of 970 and $130 \mathrm{bp}$ (Figure 1D).

Of the 52 landraces of basmati rice and 5 cultivars, 10 landraces and 2 cultivars showed the presence of more than one BB-resistance genes (Table 2). Landrace Basmati-122 possessed homozygous resistance alleles for $\mathrm{xa} 5$ and $\mathrm{Xa}$ and a heterozygous status for $\mathrm{Xa} 4$. Cultivars Basmati-2000 and Basmati-385 and landraces Basmati-106, Basmati-189 and Basmati-208 contained the genes $\mathrm{Xa} 4$ and $\mathrm{Xa}$, whereas landraces Basmati-427 and Basmati-433 contained the combination of $x a 5$ and $X a 7$ genes. The combination of $X a 7$ and $x a 13$ resistance genes was found in landraces Basmati-48, Basmati-51A, Basmati-334, and Basmati-370A. 


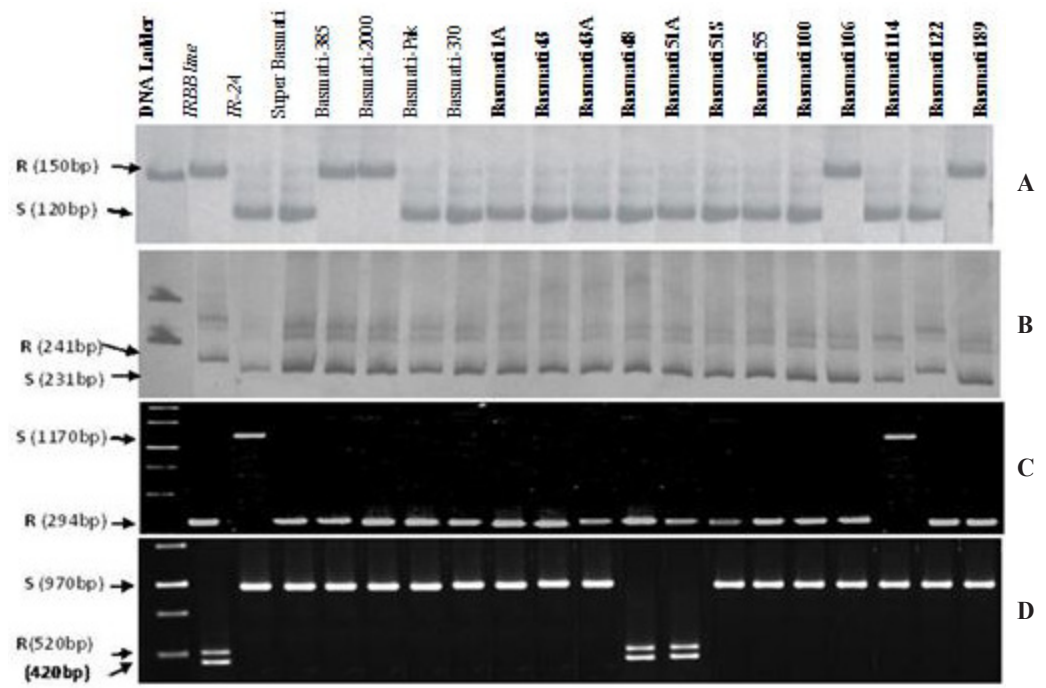

Figure 1. Status of bacterial blight resistance genes $\mathrm{Xa4}$ (A); xa5 (B);Xa7 (C), and $x a 13$ (D) in IRBB gene differential lines (in italic), 12 basmati landraces (in bold) and five basmati cultivars. R and $\mathrm{S}$ indicate amplicons correspondent to resistance and susceptibility, respectively.

Table 2. Status of bacterial blight genes in 52 basmati landraces, basmati cultivars (in bold) and gene differential IRBB lines (in italic).

\begin{tabular}{|c|c|c|c|c|c|c|c|c|c|c|c|}
\hline \multirow[t]{2}{*}{ Serial No. } & \multirow[t]{2}{*}{ Accession } & \multicolumn{4}{|c|}{ Gene/Marker } & \multirow[t]{2}{*}{ Serial No. } & \multirow[t]{2}{*}{ Accession } & \multicolumn{4}{|c|}{ Gene/Marker } \\
\hline & & Xa4/MP1-2 & $x a 5 / \mathrm{RM} 122$ & $X a 7 / \mathrm{M} 5$ & xa13/RG136 & & & Xa4/MP1-2 & $x a 5 /$ RM122 & Xa7/M5 & xal3/RG136 \\
\hline 1 & Basmati-1A & $\mathrm{S}$ & $\mathrm{S}$ & $\mathrm{R}$ & $\mathrm{S}$ & 32 & Basmati-370 & $\mathrm{S}$ & $\mathrm{S}$ & $\mathrm{R}$ & $\mathrm{S}$ \\
\hline 2 & Basmati-43 & $\mathrm{S}$ & $\mathrm{S}$ & $\mathrm{R}$ & $\mathrm{S}$ & 33 & Basmati-370A & $\mathrm{S}$ & $\mathrm{S}$ & $\mathrm{R}$ & $\mathrm{R}$ \\
\hline 3 & Basmati-43A & S & S & $\mathrm{R}$ & $\mathrm{S}$ & 34 & Basmati-370B & $\mathrm{S}$ & $\mathrm{S}$ & $\mathrm{R}$ & S \\
\hline 4 & Basmati-48 & $\mathrm{S}$ & $\mathrm{S}$ & $\mathrm{R}$ & $\mathrm{R}$ & 35 & Basmati-372 & $\mathrm{S}$ & $\mathrm{S}$ & $\mathrm{R}$ & $\mathrm{S}$ \\
\hline 5 & Basmati-51A & $\mathrm{S}$ & $\mathrm{S}$ & $\mathrm{R}$ & $\mathrm{R}$ & 36 & Basmati-372A & $\mathrm{S}$ & $\mathrm{S}$ & $\mathrm{R}$ & $\mathrm{S}$ \\
\hline 6 & Basmati-51S & S & $\mathrm{S}$ & $\mathrm{R}$ & $\mathrm{S}$ & 37 & Basmati-372B & S & $\mathrm{S}$ & $\mathrm{R}$ & S \\
\hline 7 & Basmati-55 & S & $\mathrm{S}$ & $\mathrm{R}$ & $\mathrm{S}$ & 38 & Basmati-375 & S & S & $\mathrm{R}$ & S \\
\hline 8 & Basmati-100 & S & $\mathrm{S}$ & $\mathrm{R}$ & $\mathrm{S}$ & 39 & Basmati-375A & S & S & $\mathrm{R}$ & S \\
\hline 9 & Basmati-106 & $\mathrm{R}$ & $\mathrm{S}$ & $\mathrm{R}$ & $\mathrm{S}$ & 40 & Basmati-376 & $\mathrm{S}$ & $\mathrm{S}$ & $\mathrm{R}$ & $\mathrm{S}$ \\
\hline 10 & Basmati-114 & $\mathrm{S}$ & $\mathrm{S}$ & $\mathrm{S}$ & $\mathrm{S}$ & 41 & Basmati-377 & $\mathrm{S}$ & $\mathrm{S}$ & $\mathrm{R}$ & $\mathrm{S}$ \\
\hline 11 & Basmati-122 & $\mathrm{H}$ & $\mathrm{R}$ & $\mathrm{R}$ & $\mathrm{S}$ & 42 & Basmati-381 & $\mathrm{S}$ & $\mathrm{S}$ & $\mathrm{R}$ & $\mathrm{S}$ \\
\hline 12 & Basmati-123 & S & $\mathrm{S}$ & $\mathrm{R}$ & $\mathrm{S}$ & 43 & Basmati-388 & S & S & $\mathrm{R}$ & S \\
\hline 13 & Basmati-128 & S & $\mathrm{S}$ & $\mathrm{R}$ & $\mathrm{S}$ & 44 & Basmati-92 & S & $\mathrm{S}$ & $\mathrm{R}$ & $\mathrm{S}$ \\
\hline 14 & Basmati-134 & $\mathrm{S}$ & $\mathrm{S}$ & $\mathrm{R}$ & $\mathrm{S}$ & 45 & Basmati-397 & $\mathrm{S}$ & $\mathrm{S}$ & $\mathrm{R}$ & $\mathrm{S}$ \\
\hline 15 & Basmati-136 & S & $\mathrm{S}$ & $\mathrm{R}$ & $\mathrm{S}$ & 46 & Basmati-410 & S & $\mathrm{S}$ & $\mathrm{R}$ & $\mathrm{S}$ \\
\hline 16 & Basmati-137 & $\mathrm{S}$ & $\mathrm{S}$ & $\mathrm{R}$ & $\mathrm{S}$ & 47 & Basmati-427 & $\mathrm{S}$ & $\mathrm{R}$ & $\mathrm{R}$ & $\mathrm{S}$ \\
\hline 17 & Basmati-140 & S & $\mathrm{S}$ & $\mathrm{R}$ & $\mathrm{S}$ & 48 & Basmati-433 & S & $\mathrm{R}$ & $\mathrm{R}$ & $\mathrm{S}$ \\
\hline 18 & Basmati-187 & $\mathrm{S}$ & $\mathrm{S}$ & $\mathrm{R}$ & $\mathrm{S}$ & 49 & Basmati-443 & $\mathrm{S}$ & $\mathrm{S}$ & $\mathrm{R}$ & $\mathrm{S}$ \\
\hline 19 & Basmati-189 & $\mathrm{R}$ & $\mathrm{S}$ & $\mathrm{R}$ & $\mathrm{S}$ & 50 & Basmati-Kamoh & S & S & $\mathrm{R}$ & $\mathrm{S}$ \\
\hline 20 & Basmati-208 & $\mathrm{R}$ & $\mathrm{H}$ & $\mathrm{R}$ & $\mathrm{S}$ & 51 & CP-1 & $\mathrm{S}$ & $\mathrm{S}$ & $\mathrm{R}$ & $\mathrm{S}$ \\
\hline 21 & Basmati-213 & S & $\mathrm{S}$ & $\mathrm{R}$ & $\mathrm{S}$ & 52 & $\mathrm{CP}-2$ & S & S & $\mathrm{R}$ & $\mathrm{S}$ \\
\hline 22 & Basmati-213C & $\mathrm{S}$ & $\mathrm{S}$ & $\mathrm{R}$ & $\mathrm{S}$ & 53 & Super Basmati & $\mathrm{S}$ & $\mathrm{s}$ & $\mathrm{R}$ & $\mathrm{S}$ \\
\hline 23 & Basmati-242 & $\mathrm{S}$ & $\mathrm{S}$ & $\mathrm{R}$ & $\mathrm{S}$ & 54 & Basmati-370 & $\mathrm{S}$ & $\mathrm{S}$ & $\mathrm{R}$ & $\mathrm{S}$ \\
\hline 24 & Basmati-242A & S & $\mathrm{S}$ & $\mathrm{R}$ & $\mathrm{S}$ & 55 & Basmati-2000 & $\mathrm{R}$ & $\mathrm{S}$ & $\mathrm{R}$ & $\mathrm{S}$ \\
\hline 25 & Basmati-249 & S & $\mathrm{S}$ & $\mathrm{R}$ & $\mathrm{S}$ & 56 & Basmati-Pak & S & S & $\mathrm{R}$ & $\mathrm{S}$ \\
\hline 26 & Basmati-286 & S & $\mathrm{S}$ & $\mathrm{R}$ & $\mathrm{S}$ & 57 & Basmati-385 & $\mathrm{R}$ & S & $\mathrm{R}$ & $\mathrm{S}$ \\
\hline 27 & Basmati-312 & S & $\mathrm{S}$ & $\mathrm{R}$ & $\mathrm{S}$ & 58 & IRBB-4 & $\mathrm{R}$ & - & - & - \\
\hline 28 & Basmati-320 & $\mathrm{S}$ & $\mathrm{S}$ & $\mathrm{R}$ & $\mathrm{S}$ & 59 & IRBB-5 & - & $\mathrm{R}$ & - & - \\
\hline 29 & Basmati-334 & S & $\mathrm{S}$ & $\mathrm{R}$ & $\mathrm{R}$ & 60 & IRBB-7 & - & - & $\mathrm{R}$ & - \\
\hline 30 & Basmati-365 & $\mathrm{S}$ & $\mathrm{S}$ & $\mathrm{R}$ & $\mathrm{S}$ & 61 & IRBB-13 & - & - & - & $\mathrm{R}$ \\
\hline 31 & Basmati-365A & $\mathrm{S}$ & $\mathrm{S}$ & $\mathrm{R}$ & $\mathrm{S}$ & 62 & $I R-24$ & $\mathrm{~S}$ & $\mathrm{~S}$ & $\mathrm{~S}$ & $\mathrm{~S}$ \\
\hline
\end{tabular}

$\mathrm{S}=$ susceptible genotype; $\mathrm{R}$ : resistant genotype; $\mathrm{H}=$ heterozygote . 


\section{DISCUSSION}

Rice is a highly domesticated crop, and domestication processes are reported to be accompanied by genetic erosion, which causes a reduction in genetic diversity among traditional varieties and gradual loss of landraces from the fields (Brush, 2000). Modern rice cultivars have been developed through the hybridization of elite lines and subsequent selection for yield and quality traits, which resulted in a loss of useful genes to combat biotic and abiotic threats. The picture is even worse for modern Pakistani-bred basmati cultivars, where all the 7 cultivated varieties have been developed either through direct selection from landrace Basmati-370 or from its cross with the exotic line, $\mathrm{TN}-1$. Bacterial blight is a devastating rice disease, and the current basmati cultivars with a narrow genetic base have lost BB-resistance genes. Therefore, basmati growers experience significant yield loss every year. This genetic bottleneck can be efficiently resolved by incorporating and pyramiding multiple BB-resistance genes through marker-assisted breeding.

Several BB-resistance genes have been identified and characterized in non-aromatic rice and incorporated and pyramided through MAS to develop resistant cultivars (Perumalsamy et al., 2010; Rajpurohit et al., 2010). However, their incorporation into the basmati background impairs the superfine grain quality and aroma of basmati rice. The identification and utilization of genes conferring BB-resistance genes from basmati landraces to high-yielding susceptible, commercial basmati cultivars is a more efficient way to combat BB disease without compromising the aroma and grain quality and will also help broaden the genetic base of Basmati varieties. We report here the status of dominant (Xa4 and $\mathrm{Xa}$ ) and recessive ( $x a 5$ and $x a 13$ ) BB-resistance genes in a set of 52 aromatic basmati landraces being maintained since 1926 at Rice Research Institute, Kala Shah Kaku, Pakistan (Akhter M, personal communication).

Among the major resistance genes, $X a 7$ was initially explored in cultivar DV85 (International Rice Research Institute, accession No. 8839) and subsequently transferred to cultivar IR24 to develop IRBB7 through recurrent backcrossing (Sidhu et al., 1978). Considerable evidence has proved that the $\mathrm{Xa} 7$ gene is an important durable resistance gene since it has no protein similar to other cloned BB-resistance genes, including Xa1, Xa3, Xa13, Xa21, Xa26, and Xa27 (Iyer and McCouch, 2004; Chen et al., 2008). However, the prevalence of Xa7, found in this study, in basmati landraces and commercial cultivars, reflects its ineffectiveness to control BB in the local environment, which may be attributed to the presence of diverse inoculums (Sukhwinder-Singh et al., 2003).

Another dominant BB-resistance gene, Xa4, has been mapped on chromosome 11 (Petpisit et al., 1977). The cultivars pyramided with the $\mathrm{Xa} 4$ gene exhibited a wider spectrum of resistance at almost all stages of plant growth. We report here the presence of Xa4 in 3 basmati landraces, i.e., Basmati-106, Basmati-189 and Basmati-208, in addition to confirming a previous report of its presence in the commercial cultivars Basmati-2000 and Basmati-385, which are moderately resistant to BB (Arif et al., 2008).

The recessive genes $x a 5$ and $x a 13$ prevented BB epidemics by conferring resistance to a wide spectrum of $X$. oryzae races and have been mapped on chromosomes 5 and 8 , respectively (Yoshimura et al., 1995; Zhang et al., 1996). MAS is a pivotal tool for the pyramiding of such recessive genes in the presence of dominant genes such as $\mathrm{Xa} 4$ and $\mathrm{Xa}$. Successful pyramiding of these genes has delivered very promising results (Perumalsamy et al., 2010). Lack of both genes in commercial cultivars and their presence in the landraces tested in this study proved their erosion during the development of modern basmati rice cultivars. 


\section{CONCLUSION}

This study indicates the presence of $x a 5$ and $x a 13$ genes in basmati landraces, which lacks in modern basmati rice cultivars. The use of the landraces as a donor parent in hybridization with cultivars Basmati-385 and Basmati-2000, which contain the genes $\mathrm{Xa4}$ and $\mathrm{Xa7}$, will expedite efforts to develop BB resistance in basmati rice cultivar through an MAS-based pyramiding approach, without compromising aroma and grain quality.

\section{ACKNOWLEDGMENTS}

Research supported by the Punjab Agricultural Research Board, Lahore, Pakistan (Project \#49 "Control of bacterial leaf blight through management and resistant varieties").

\section{REFERENCES}

Arif M, Jaffar M, Babar M, Sheikh AM, et al. (2008). Identification of bacterial blight resistance genes Xa4 in Pakistani rice germplasm using PCR. Afr. J. Biotechnol. 7: 541-545.

Blair MW and McCouch SR (1997). Microsatellite and sequence-tagged site markers diagnostic for the rice bacterial leaf blight resistance gene xa-5. Theor. Appl. Genet. 95: 174-184.

Brush SB (2000). The Issues of in Situ Conservation of Crop Genetic Resources. In: Genes in the Field: On-Farm Conservation of Crop Diversity (Brush SB, ed.). IPGRI, IDRC. Lewis Publishers, Chelsea, 3-26.

Chen S, Huang Z, Zeng L, Yang J, et al. (2008). High-resolution mapping and gene prediction of Xanthomonas oryzae pv. oryzae resistance gene Xa7. Mol. Breed. 22: 433-441.

Chen S, Liu X, Zeng L, Ouyang D, et al. (2011). Genetic analysis and molecular mapping of a novel recessive gene xa34(t) for resistance against Xanthomonas oryzae pv. oryzae. Theor. Appl. Genet. 122: 1331-1338.

Chen X, Temnykh S, Xu Y, Cho YG, et al. (1997). Development of a microsatellite framework map providing genomewide coverage in rice (Oryza sativa L.). Theor. Appl. Genet. 95: 553-567.

Iyer AS and McCouch SR (2004). The rice bacterial blight resistance gene xa5 encodes a novel form of disease resistance. Mol. Plant Microbe Interact. 17: 1348-1354.

Khush GS (2005). What it will take to feed 5.0 billion rice consumers in 2030. Plant Mol. Biol. 59: 1-6.

Ma BJ, Wang WM, Zhao B, Zhou YL, et al. (1999). Studies of PCR marker for the rice bacterial blight resistance gene Xa-4. Hereditas 21: 9-12.

Perumalsamy S, Bharani M, Sudha M, Nagarajan P, et al. (2010). Functional marker-assisted selection for bacterial leaf blight resistance genes in rice (Oryza sativa L.). Plant Breed. 129: 400-406.

Petpisit V, Khush GS and Kauffman HE (1977). Inheritance of resistance to bacterial blight in rice. Crop Sci. 17: 551-554.

Porter BW, Chittoor JM, Yano M, Sasaki T, et al. (2003). Development and mapping of markers linked to the rice bacterial blight resistance gene Xa7. Crop Sci. 43: 1484-1492.

Rajpurohit D, Kumar R, Kumar M, Paul P, et al. (2010). Pyramiding of two bacterial blight resistance and a semidwarfing gene in Type 3 Basmati using marker-assisted selection. Euphytica 178: 111-126.

Sidhu GS, Khush GS and Mew TW (1978). Genetic analysis of bacterial blight resistance in seventy-four cultivars of rice, Oryza sativa L. Theor. Appl. Genet. 53: 105-111.

Srinivasan B and Gnanamanickam S (2005). Identification of a new source of resistance in wild rice, Oryza rufipogon to bacterial blight of rice caused by Indian strains of Xanthomonas oryzae pv. oryzae. Curr. Sci. 88: 1229-1231.

Sukhwinder-Singh, Sodhi M, Vikal Y, George MLC, et al. (2003). DNA fingerprinting and virulence analysis of Xanthomonas oryzae pv. oryzae isolates from Punjab, northern India. Euphytica 130: 107-115.

Yoshimura S, Yoshimura A, Iwata N, McCouch SR, et al. (1995). Tagging and combining bacterial blight resistance genes in rice using RAPD and RFLP markers. Mol. Breed. 1: 375-387.

Zhang G, Angeles ER, Abenes MLP, Khush GS, et al. (1996). RAPD and RFLP mapping of the bacterial blight resistance gene Xa-13 in rice. Theor. Appl. Genet. 93: 65-70. 